\title{
Possible mechanisms of underlying thrombosis in neurofibromatosis: a neurofibromatosis case presenting with portal vein thrombosis
}

\author{
Nörofibromatoziste altta yatan trombozun olası mekanizmaları: \\ Portal ven trombozunun eşlik ettiği bir nörofibromatozis olgusu
}

Elif Ertürk, Aydan Taka Küçük, Semahat Gürlek Yıldırım, Faruk Özalp, Zehra Betül Paköz, Harun Akar

Department of Internal Medicine, Tepecik Training and Research Hospital, Izmir, Turkey

\begin{abstract}
In this article, we present a 54-year-old female patient with neurofibromatosis and portal vein thrombosis. We investigated the conditions predisposing to thrombosis. Our findings revealed no conditions predisposing to thrombosis except neurofibromatosis.

Keywords: Neurofibromatosis; neurofibromatosis type 1 vasculopathy; portal vein thrombosis.

$\ddot{O Z Z}$

Bu yazıda, nörofibromatozisi ve portal ven trombozu olan 54 yaşında bir kadın hasta sunuldu. Tromboza zemin hazırlayan durumlar araştıııldı. Bulgularımız nörofibromatozis dışında tromboza zemin hazırlayan hiçbir durum ortaya koymadı.

Anahtar sözcükler: Nörofibromatozis; nörofibromatozis tip 1 vaskülopatisi; portal ven trombozu.
\end{abstract}

Neurofibromatosis type 1 (NF1) is an autosomal dominant genetic disorder with an approximate incidence of $1 / 2500-3000 .{ }^{[1]}$ Neurofibromatosis type 1 is also known as von Recklinghausen disease. The diagnosis of NF1 is done using at least two of the following clinical manifestations: (i) café au lait spots; (ii) skin-fold freckling in non-sun-exposed areas; (iii) iris Lisch nodules; (iv) neurofibromas; (v) optic pathway gliomas; (vi) characteristic bony dysplasia of the long bones and sphenoid wing; and (vii) a first-degree relative with NF1. ${ }^{[1]}$ Infrequently, underrecognized cardiovascular complications may develop in these patients. ${ }^{[1]}$ The most important being aneurysms or stenoses in the aortic, renal and mesenteric circulation. ${ }^{[2]}$ Portal vein thrombosis (PVT) in patients with a healthy liver is considered to be due to inherited or acquired prothrombotic conditions. ${ }^{[3]}$ However, no apparent cause for PVT can be detected in some patients. The main risk factors for venous thromboembolism (VTE) include prior thromboembolism, recent major surgery, trauma, immobilization, antiphospholipid antibodies, malignancy, pregnancy, oral contraceptives and myeloproliferative disorders. A neurofibromatosis case presenting with chronic abdominal pain, ascites and portal vein trombosis is discussed below.

\section{CASE REPORT}

The patient is a 54-year-old woman with type 2 diabetes mellitus and coronary heart disease who presented with pain in the left hypochondrium area and was referred for evaluation. Since the portal and venous thrombosis were detected in 
the examination performed at another center, the patient was admitted to the general internal medicine clinic in order to investigate the etiology of portal and thrombosis. Initially, a general medical examination showed no abnormality other than neurofibromatosis findings such as neurofibromas (Figure 1), Café au lait spots (Figure 1), axillary dysplasia, and Lisch nodules (Figure 2). Patient follow-up was continued in the form of a neurofibromatosis case in which the etiology of portal vein thrombosis was investigated. This case illustrates a classic presentation of neurofibromatosis and underlines the complexity in determining the etiology of portal vein thrombosis. The etiology of portal vein thrombosis in this case remains unclear. It is postulated that it may be due to vascular changes seen in neurofibromatosis. Acute and chronic portal vein thrombosis distinction is important.

The physical examination revealed neurofibromas, Café au lait spots, axillary freckling and Lisch nodules. Based on this presentation, a diagnosis of neurofibromatosis was suspected. Neurofibromatosis gene mutation could not be studied. Erythrocyte sedimentation rate, C-reactive protein (CRP) and procalcitonin levels were within normal levels. Portal Doppler ultrasonography showed collateral formations compatible with

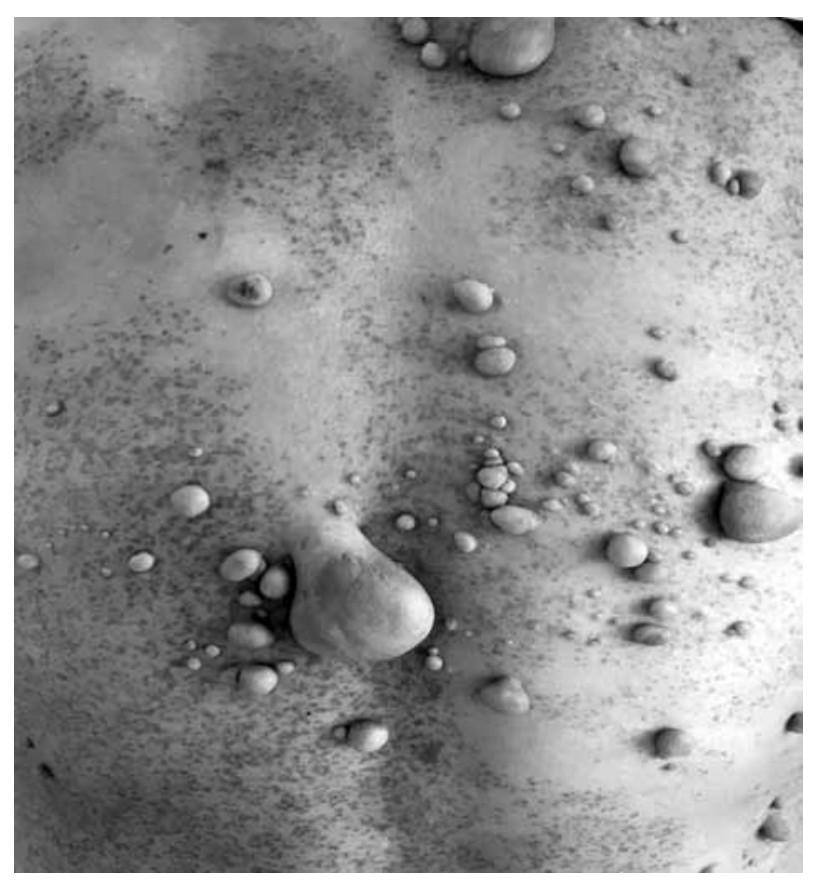

Figure 1. Neurofibromas and Café au lait spots. chronic portal vein thrombosis. Abdominal computed tomography (CT) showed chronic portal venous thrombosis with collateral vessels. Contrast-enhanced thorax and neck CT were requested to exclude malign diseases. Paroxysmal nocturnal hemoglobinuria $(\mathrm{PNH})$ clone was found to be negative. Blood tests were ordered to exclude vasculitis and hypercoagulability. Serum anticyclic citrullinated peptide (anti CCP), anti-doublestranded DNA (anti dsDNA), cytoplasmic and perinuclear anti-neutrophil antibodies (c-ANCA, p-ANCA), anti-nuclear antibodies (ANA), protein $\mathrm{C}$, protein $\mathrm{S}$ and anti-thrombin 3 activity and serum homocystein were within normal limits. Since Factor V Leiden mutation (G1691A) and prothrombin (Factor 2) gene mutation (G20210A) were not detected, hereditary thrombophilia was excluded. Antiphospholipid and anticardiolipin antibodies were negative. Endoscopy-colonoscopy was performed in terms of inflammatory bowel diseases and malignancy, and extensive varicose veins were detected in the gastrointestinal tract (Figure 3,4$)$. There was no malignant focus on imaging. Portal venous thrombosis was considered chronic due to the presence of collateral vessels. Anticoagulant therapy was not considered because of the risk of bleeding in multiple varicose veins. On carotid Doppler ultrasonography, occlusion in left common carotid artery was detected.

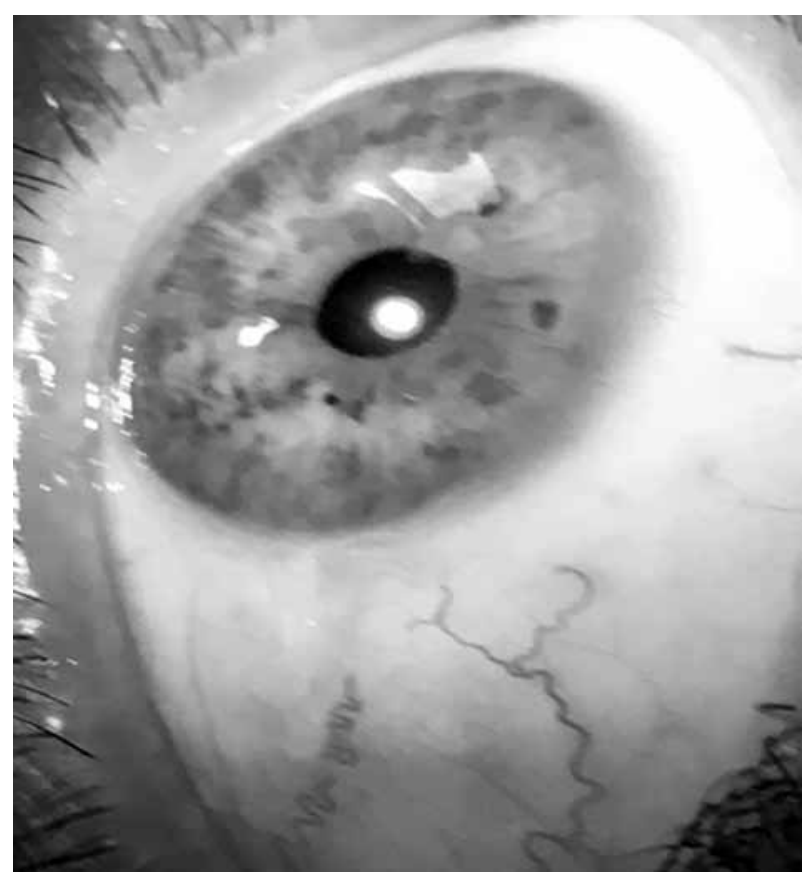

Figure 2. Lisch nodules. 


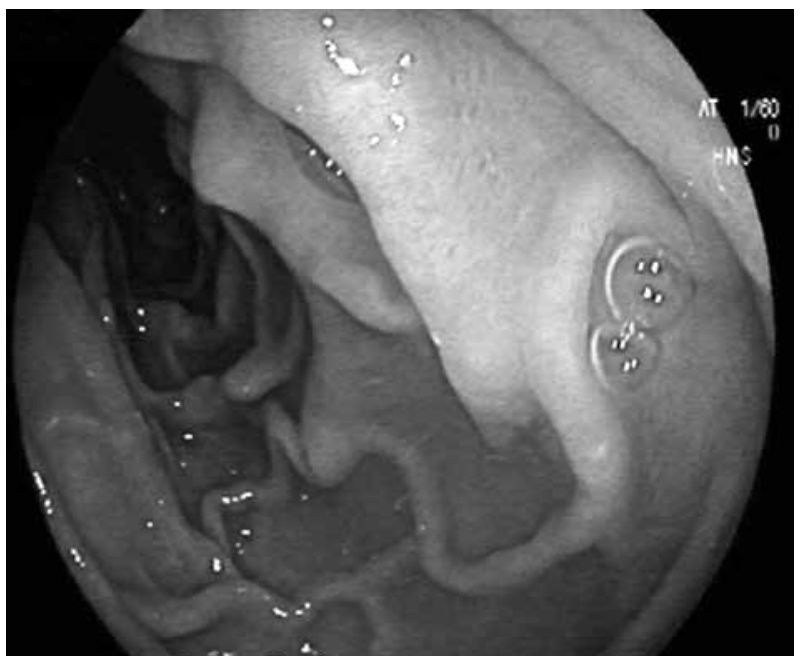

Figure 3. Gastric varices.

Acetylsalicylic acid treatment began due to the presence of chronic portal vein thrombosis and carotid plaque. Propranolol was administered for prophylaxis because of the common varices in the gastrointestinal tract. In the meantime, when testing for thrombosis susceptibility was done, the patient's blood sugar regulation was provided.

\section{DISCUSSION}

Neurofibromatosis type 1 is a relatively common single gene disorder, and heterozygous mutations in the NF1 gene result in a neurofibromin (NF) protein which does not have a function..$^{[1]}$ Despite a common association with the neurocutaneous properties of NF1, pathology may involve many tissues not derived from the neural crest. ${ }^{[1]}$ Vascular abnormalities are seen in a wide spectrum of patients with NF1; the most common are aneurysms or stenoses in aortic, renal, and mesenteric circulation..$^{[2]}$ Neurofibromatosis type 1 vasculopathy has been described to represent aneurysms, stenoses and arteriovenous malformations seen in patients with NF1. ${ }^{[2]}$ Neurofibromin is expressed in blood vessels of the endothelium and smooth muscle cells, and it is thought that NF1 vasculopathy may result in a change in the function of NF in these cells. ${ }^{[4]}$

Neurofibromatosis and portal vein thrombosis association could not be found in the literature. The underlying mechanism of thrombosis seen in neurofibromatosis is not known exactly. We believe that portal venous thrombosis can be

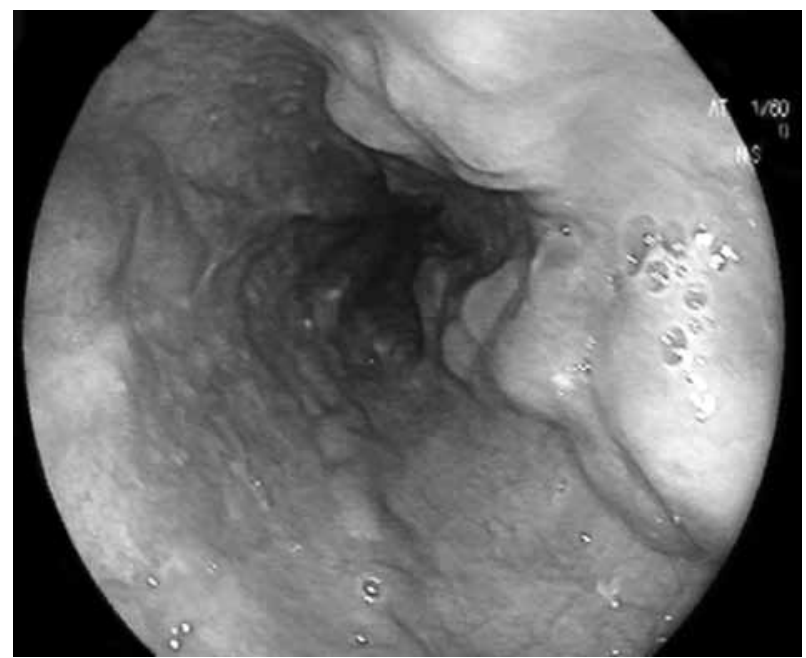

Figure 4. Esophageal varices.

attributed to the presence of neurofibromatosis. The vascular manifestations of neurofibromatosis include aneurysmal and stenotic changes in large and medium-sized arteries. ${ }^{[5,6]}$ The vascular changes seen in neurofibromatosis include aneurysms of the aorta, vertebral arteries, carotid artery, thyrocervical trunk, and mesenteric and celiac arteries. ${ }^{[7]}$ The vascular pathology leading to aneurysm formation in these lesions includes intimal proliferation causing stenosis, medial thinning and fragmentation of elastic tissue. ${ }^{[8,9]}$ Pathological examination of the reported cases with neurofibromatosis and myocardial infarction showed minimal changes consistent with neurofibromatosis, coronary artery aneurysm and intraluminal thrombus. ${ }^{[10,11]}$

Obtaining the role of NF in the maintenance and repair of blood vessels may lead to new approaches in the treatment of NF1 vasculopathy. ${ }^{[4]}$ An autosomal dominant mutation in NF1 leads to a deficiency of NF1, a protein with a tumor suppressor function in the Rasextracellular regulated kinase pathway. ${ }^{[12]}$ Khelifa et al. ${ }^{[12]}$ described a patient with NF and cutaneous vasculopathy treated with imatinib, a tyrosine kinase inhibitor.

This patient displayed signs of neurofibromatosis. The limitation of this case report is the inability to study the neurofibromatosis gene mutation. Although the exact mechanism of portal vein thrombosis in this case is unknown, there is some evidence in the literature to 
suggest that neurofibromatosis may increase the tendency for thrombosis. The underlying cause of thrombosis should be carefully investigated in terms of neurofibromatosis. Internists should be aware of the potential for increased vascular complications among patients with NF1.

\section{Declaration of conflicting interests}

The authors declared no conflicts of interest with respect to the authorship and/or publication of this article.

\section{Funding}

The authors received no financial support for the research and/or authorship of this article.

\section{REFERENCES}

1. Conforti R, Cirillo M, Marrone V, Galasso R, Capaldo G, Giugliano T, et al. Giant thrombosed intracavernous carotid artery aneurysm presenting as Tolosa-Hunt syndrome in a patient harboring a new pathogenic neurofibromatosis type 1 mutation: a case report and review of the literature. Neuropsychiatr Dis Treat 2014;10:135-40.

2. Oderich GS, Sullivan TM, Bower TC, Gloviczki P, Miller DV, Babovic-Vuksanovic D, et al. Vascular abnormalities in patients with neurofibromatosis syndrome type I: clinical spectrum, management, and results. J Vasc Surg 2007;46:475-84.

3. Belli L, Romani F, Riolo F, Rondinara G, Aseni P, Di Stefano M, et al. Thrombosis of portal vein in absence of hepatic disease. Surg Gynecol Obstet 1989;169:46-9.

4. Hamilton SJ, Friedman JM. Insights into the pathogenesis of neurofibromatosis 1 vasculopathy. Clin Genet 2000;58:341-4.

5. Pentecost M, Stanley $\mathrm{P}$, Takahashi M, Isaacs $\mathrm{H}$ Jr. Aneurysms of the aorta and subclavian and vertebral arteries in neurofibromatosis. Am J Dis Child 1981;135:475-7.

6. Bloor K, Williams RT. Neurofibromatosis and coarctation of the abdominal aorta with renal artery involvement. Br J Surg 1963;50:811-3.

7. Henley FT, Kaude JV. Angiographic findings in two cases of generalized neurofibromatosis. Vasc Surg 1973;7:60-6.

8. Greene JF Jr, Fitzwater JE, Burgess J. Arterial lesions associated with neurofibromatosis. Am J Clin Pathol 1974;62:481-7.

9. Fye KH, Jacobs RP, Roe RL. Vascular manifestations of von Recklinghausen's disease. West $\mathrm{J}$ Med 1975;122:110-6.

10. Halper J, Factor SM. Coronary lesions in neurofibromatosis associated with vasospasm and myocardial infarction. Am Heart J 1984;108:420-2.

11. Kandarpa K, Stoll JF, Reiss C, Rutherford JD, Cohn LM. A case of neurofibromatosis associated with a coronary artery aneurysm and myocardial infarction. Cardiovasc Intervent Radiol 1988;11:143-5.

12. Khelifa I, Saurat JH, Prins C. Use of imatinib in a patient with cutaneous vasculopathy in the context of von Recklinghausen disease/neurofibromatosis. $\mathrm{Br} \mathrm{J}$ Dermatol 2015;172:253-6. 